\title{
INDUSTRY 4.0 AS A RESPONSE TO CONTEMPORARY STRATEGIC CHALLENGESPAPER
}

doi: 10.2478/cqpi-2019-0014

Date of submission of the article to the Editor: 30/03/2019

Date of acceptance of the article by the Editor: 8/05/2019

\section{Agnieszka Puto - orcid id: 0000-0002-1947-0753 \\ Czestochowa Technical University - Poland}

\begin{abstract}
The world economy is on the verge of technological revolution which is profoundly changing the way of the operation of enterprises. The signpost of the transformation of the world industry is the vision of Industry 4.0, which is a response to contemporary challenges and gives grounds for creating significant competitive advantages of modern enterprises. In the paper, the author attempts to respond to the question concerning what Industry 4.0 is, what opportunities it provides and what challenges it poses. The objective of the paper will be to describe the case study of the enterprise predisposing to the implementation of revolutionary changes associated with the concept of Industry 4.0.
\end{abstract}

Keywords: Industry 4.0, IoT, CPS, challenges of contemporary enterprises

\section{INTRODUCTION}

Previous considerations on the challenges of contemporary enterprises have been associated with globalization and also technological, social and cultural progress. After the third industrial revolution, which consisted in the automation of individual processes, now we are witnessing the fourth one, allowing the connection of devices within digital ecosystems and the deepening of integration inside horizontal and vertical value chains (Fig. 1). The fourth industrial era has become a challenge to contemporary enterprises. It is commonly referred to as the era of Industry 4.0 or Industry Revolution 4.0 (I.R. 4.0).

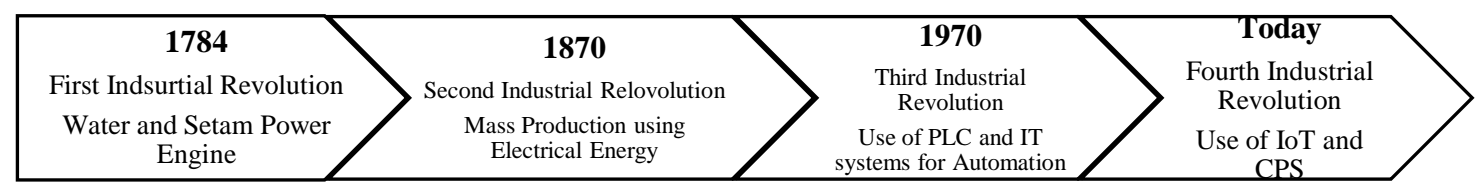

Fig. 1. Industrial eras (Vaidya, Ambad, Bhosle, 2018, p. 234)

The idea of the fourth industrial revolution is to create the fully integrated system of suppliers, producers and customers. IT solutions are to become integrated with all the sub-systems, processes and resources of the systems and networks of suppliers and 
customers. "As observed by A. Zagajewski and S. Saniuk, IT systems will, therefore, integrate the entire supply chains thus creating Cyber-Physical Systems (CPS). They will constitute open socio-technical systems, capable of the implementation of a range of new functions and operations imposed by production, logistics, sales or management. Cyber-Physical Systems should provide the collection of data, their processing and impact on the physical processes of production of customized products due to unlimited network connections with minimum involvement of humans, performing only the supervisory function (Zagajewski and Saniuk, 2018, p. 83). This causes that the era of IR 4.0 imposes specific challenges and priorities in behavior on enterprises (and also other types of organizations), it also determines their competitiveness.

The phenomenon of "the Fourth Industrial Revolution" has become the subject for discussions, analyses and development projects conducted by engineers and scientists. Search results for "Industry 4.0" in the google search engine give the result of 398000000 , which indicates the popularity of the subject matter. In the google scholar search engine, this result amounts to 1620000 , with only 1340 publications in Polish, unfortunately. Therefore, there is a gap to fill in terms of the recognition of the issue by Polish scientists. In the paper, the concept of Industry 4.0 has been characterized, most of all, on the basis of the publications in English. Also, an example of effective implementation of changes in the business model based on the idea of Industry 4.0 in the Estonian Eesti Energia company has been described.

\section{THE ESSENCE OF THE FOURTH INDUSTRIAL REVOLUTION}

The aging of the population, which now occurs in many countries of the world, particularly in economically highly developed countries (Japan, Western Europe, Scandinavian countries) and in many developing countries (China, India) simultaneously with low fertility rate in these countries will lead to population shrinkage.

The demographic forecast developed by the UN in 2010 indicates that in the next 40 years the population of Europe will begin to steadily decline to shrink by approximately $4 \%$ in 2050 and to reach the amount of 707 million people (in 2014 it amounted to 738 million people).

In European countries, the contribution of industry in generating GDP has been steadily falling since the 1980s, industrial activity has been also reducing its share in terms of activation of labor resources. Current trends in the world economy, with the slowdown in economic growth and pressure from international competition ahead, emphasize the necessity to create appropriate conditions supporting the long-term growth and development of the European industry, which will stimulate the development of industrial technologies. One of the manifestations of existing economic changes has been the emergence of new technologies, such as CyberPhysical System (CPS) and Internet of Things (IoT). Along with their development the new concept has arisen, the so called Industry 4.0, presented for the first time in Germany during Hannover Fair in 2011, which symbolizes the beginning of the $4^{\text {th }}$ industrial revolution (Lee, 2013, pp.8-10). The concept of Industry 4.0 is the consequence of the progressing digitization of industrial production and other economic sectors and management processes. The formal definition of Industry 4.0. is the following: Industry 4.0 will involve the technical integration of CPS into 
manufacturing and logistics and the use of the Internet of Things and Services in industrial processes (Kagermann et al., 2013).

Industry 4.0. is the comprehensive solution arising at the interface of engineering, information technology and knowledge of management. It can be determined as a common term combining technology and organization of value added chain (Herman, 2015). It assumes the existence of intelligent systems being networked - vertically connected with other processes within the enterprise and horizontally associated with networks creating value, which can be managed in real time from the moment of placing an order to the coordination of sales logistics. It constitutes an intelligent combination of many IT technologies used in enterprises (Göt and Gracel 2017, p. 221). As already mentioned, in this environment, two realities of operation mutually overlap:

- Physical Reality (PR),

- Virtual Reality (VR).

There is also an intensive development of different types of inter-organizational cooperation (Network Cooperation, Virtual Network), new technologies, among others, based on computerization, digitization, robotization (Cyber-Physical Systems CPS), dynamic real-time processing of a large amount of data (Big Data Analytics BDA), network connections (Internet of Things - loT; Internet of Services - loS), close partner human relationships (Cooperation, Partnering, Team Working), interorganizational ones (Strategic Partnering - SP, Knowledge Partnering - KP; Coopetition) but also the ones between machines (Machine to Machine Communications, M2M; Artificial Intelligence; Neural Networks) (Adamik, 2018, p. 82). The concept of Industry 4.0 is often identified with digital transformation of production systems, i.e. their digitization. Digitization is already present in our everyday life - this is, e.g. e-commerce, mobile Internet or social media. Also, the area of production is heading towards increasing digitization, most of all, making use of increasingly wider applications (Woliński, 2016, p. 175; Kościelniak and Puto, 2015, pp. 1052-1058): 1) management of data (Big Data) and, most of all, their effective acquisition (via different sensors) and data analysis; 2) automation, thus combining traditional manufacturing methods with artificial intelligence, allowing for reduction of errors and costs; 3) digital communication with customers, manifested in a greater participation of the final customer in creating the expected product or service; 4) communication using broadband connections to cover the entire value chain.

According to Digital Economy and Society Index (DESI), measuring the progress of the EU countries towards the digital economy and the digital society, Poland occupies the $24^{\text {th }}$ position among 28 EU member states. In the field of digital technology integration, Poland occupies a very poor $27^{\text {th }}$ position. Despite improvements in the areas such as electronic exchange of information between enterprises, radio frequency identification, social media, e-invoicing and services in the cloud, Poland has failed to improve its position in the ranking (https://ec.europa.eu/digital-singlemarket/en/scoreboard/poland). The biggest problem in the process of digitization of enterprises in Poland is lack of knowledge of existing opportunities, limited availability of employees with digital skills and lack of financing. Moreover, Polish enterprises are unwilling to invest in improving the skills of their employees in terms of digital skills or modern technologies. 


\subsection{The requirements imposed on enterprises in the face of a new industrial revolution}

The companies of tomorrow must face the changes that occur in an uncertain, turbulent environment, which is full of social, technological, political and economic transformations. The requirements imposed on enterprises in the face of a new industrial revolution have been characterized by Adamik (2018, p. 90) in four key areas, i.e. technology, strategy, structural solutions, attitudes and social competence (Table 1), thus creating a specific base of knowledge of IR 4.0.

The emerging operating conditions impose the implementation of information technology, which is to integrate production, organizational and social processes. In the area of business, the transformation of production operations occurs, from the level of modern, independently functioning enterprises to the formula of optimally organized, fully automated production environments (networks). In these networks, production, logistics and service processes of partners are strongly related through different types of sensors, machines or IT systems, thus creating the integrated Cyber-Physical Systems (CPS) communicating in real time and, on a larger scale, the so called intelligent organizations, e.g. factories, warehouses, shops. Consequently, the production and service cycles of the IR 4.0 era organization are shorter, the needs of their customers are met in real time and their service is fully automated (Adamik 2018, pp. 88-89). An important problem while implementing the fourth revolution is the issues associated with the requirements imposed on employees. The idea of the discussed concept emphasizes that its objective is not to replace human labor with machines. The change must occur within the competence of employees since the new conditions require employees with specific and simultaneously high competence and representing the attitudes which are essential in the era of IR 4.0. Additionally, organizations should be able to develop structural (Zakrzewska-Bielawska, 215, pp. 105-111) and strategic solutions (Neeley, 2015, pp. 74-81), supporting both employees and managers, adequate to the conditions.

Industry 4.0. provides enterprises with an opportunity to build competitive advantage on its basis. The direction of changes in value chains undergoing strong integration processes in products and services will be determined by the needs of customers. All of them will be better adjusted to their individual needs. This will be possible due to data analytics. The leaders being able to effectively use industrial platform will gain a significant advantage over competitors.

Table 1

Knowledge base on IR 4.0 requirements

\begin{tabular}{|c|c|c|c|}
\hline \multicolumn{4}{|c|}{ IR 4.0 key requirement areas } \\
\hline Technologies & Strategies & $\begin{array}{l}\text { Structural } \\
\text { solutions }\end{array}$ & $\begin{array}{c}\text { Attitudes and } \\
\text { social } \\
\text { competence }\end{array}$ \\
\hline $\begin{array}{l}\text { Information and } \\
\text { Communication } \\
\text { Technologies: } \\
\text { digitization, simulation } \\
\text { and forecasting } \\
\text { techniques, } \\
\text { integrated Software, } \\
\text { techniques for direct } \\
\text { communication }\end{array}$ & $\begin{array}{l}\text { Key resources: employees, } \\
\text { knowledge, relationships, } \\
\text { dynamic capabilities, modern } \\
\text { technologies } \\
\text { Strategies for development } \\
\text { and competitiveness: } \\
\text { eclectic, flexible, agile, } \\
\text { dynamic, innovative, proactive. } \\
\text { Strategies to build the }\end{array}$ & $\begin{array}{l}\text { Leading solutions: } \\
\text { organic model of } \\
\text { organization, } \\
\text { cultural openness, } \\
\text { decentralization of } \\
\text { powers, } \\
\text { empowerment, flat, } \\
\text { flexible } \\
\text { organizational }\end{array}$ & $\begin{array}{l}\text { Competence: } \\
\text { expertise, ability to } \\
\text { learn, teamwork } \\
\text { skills, ability to work } \\
\text { in multicultural } \\
\text { environment, skills, } \\
\text { teleworking of } \\
\text { knowledge languages, } \\
\text { foreign }\end{array}$ \\
\hline
\end{tabular}




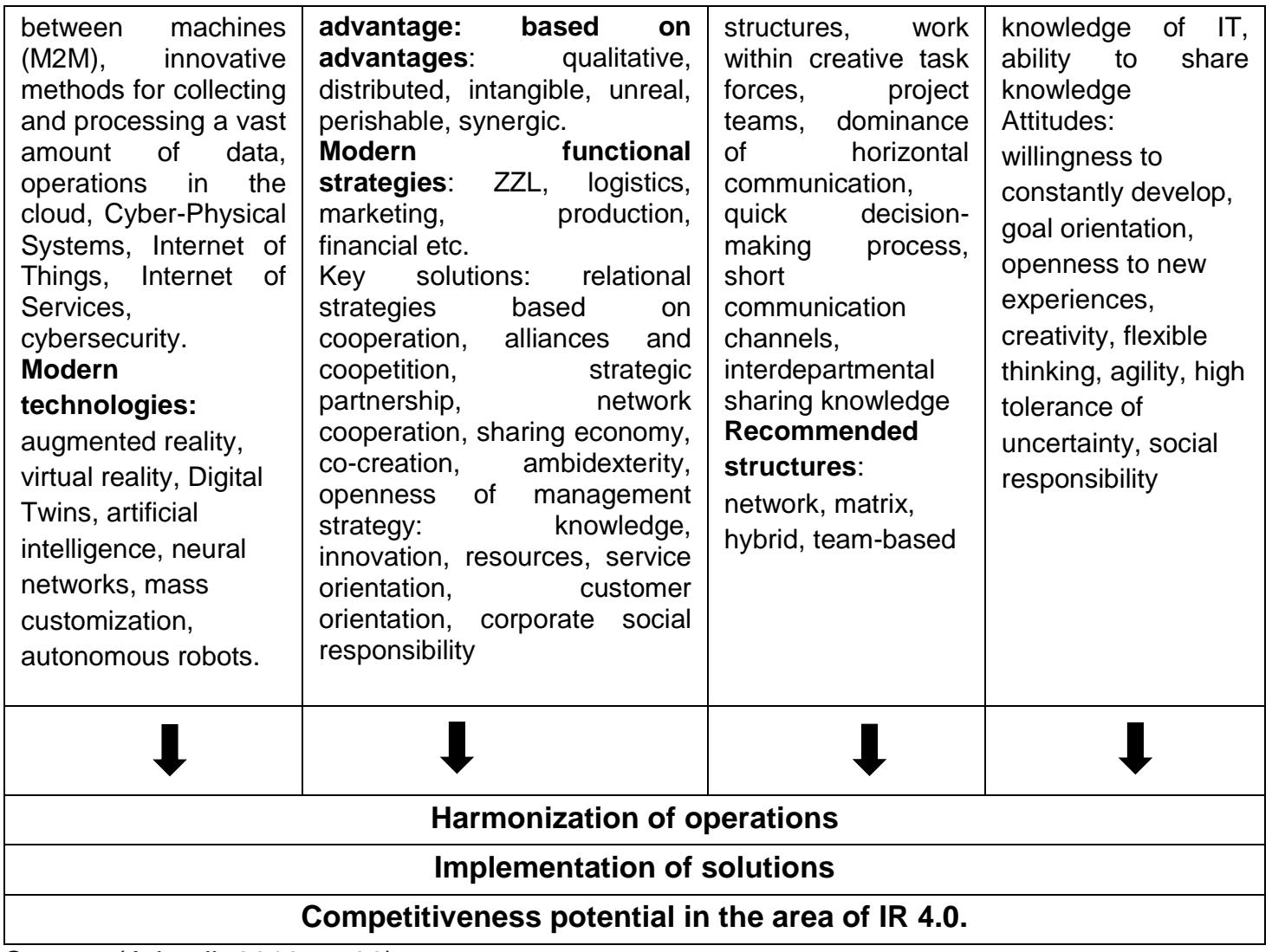

Source: (Adamik 2018, p. 90)

\section{THE BENEFITS RESULTING FROM IR 4.0.}

The concept of Industry 4.0 is oriented to high productivity of industrial systems and high profitability of the implemented projects. There is indicated a range of benefits which may result from its application. An increase in production flexibility or organization of production of more customized products deserve a special attention. This means the possibility of meeting customer expectations - the product user without loss to the profitability of the production process due to dynamic adjustment of autonomous modules of the entire process of preparation, production and delivery of the product to the customer, using IoT and information recorded in Big Data and Cloud Computing (Olszewski 2016, pp. 13-28).

Industry 4.0 ensures the availability of all important information from all processes in real time via the network. Such a solution also allows for extracting some optimal data from the flow of information at any moment. The connection of people, objects and systems with a dynamic self-organizing network allows for following the data of the key importance for the enterprise, which can be subsequently optimized by different criteria - such as costs, availability of machines and means of production, and also the monitoring of consumption of resources and energy. 
Table 2

How Industry 4.0 affects an increase in revenues, performance and cost reduction

\begin{tabular}{|c|c|}
\hline Additional revenues from: & Reduced costs and better performance due to: \\
\hline 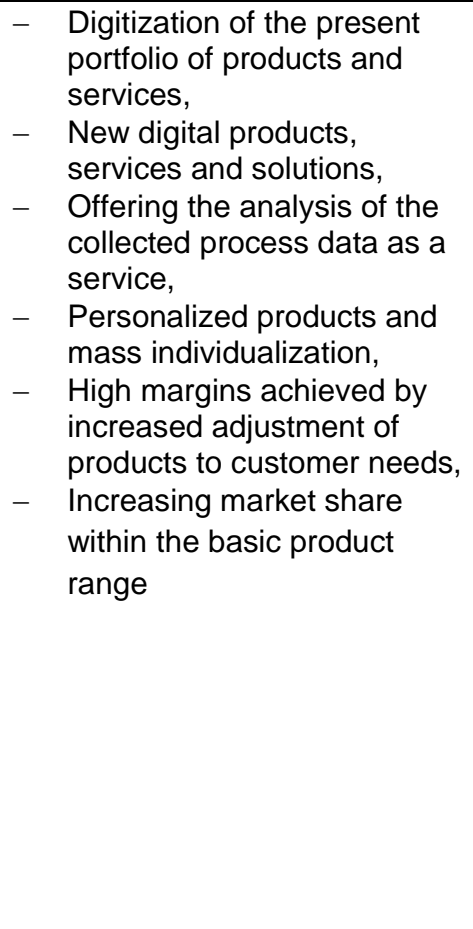 & $\begin{array}{l}\text { - } \begin{array}{l}\text { Quality control in real time based on data analysis, } \\
\text { - }\end{array} \text { Modular, flexible and customized production concepts, } \\
\text { - } \text { Information acquired in real time on deviations in production } \\
\text { processes and products, augmented reality and optimization } \\
\text { due to data analytics, } \\
\text { - } \quad \text { Possibilities of prediction concerning the operation of key } \\
\text { assets, through the use of algorithms to optimize, repair and } \\
\text { maintain the schedule and operating time of assets, } \\
\text { - } \quad \text { High margins achieved by increased adjustment of products to } \\
\text { customer needs } \\
\text { - Vertical integration of sensors through MES systems, } \\
\text { Production planning in real time for better machine utilization } \\
\text { and higher performance } \\
\text { - Increasing market share within the basic product range } \\
\text { - Horizontal integration and the track-and-trace system - control } \\
\text { of the flow of products for better inventory management and } \\
\text { logistics optimization } \\
\text { Digitization and automation of processes for optimal use of } \\
\text { human resources and more rapid operational activities } \\
\text { Systemic, comprehensive and optimal planning in real time } \\
\text { and horizontal cooperation using platforms for production } \\
\text { planning located in the cloud } \\
\text { Increasing the scale through an increase in market share of } \\
\text { key products }\end{array}$ \\
\hline
\end{tabular}

Source: (Raport Przemysł 4.0., 2018)

The benefits for the enterprise due to "Industry 4.0" will be observed in the following aspects (Kiraga, 2016 p. : 1603)

- Savings: a) performance of means of production due to high level of modularity; b) optimized processes due to high transparency of the created and possessed resources.

- Flexibility: a) the cost of production of single items comparable with mass production; b) increased productivity; c) cost-effective, flexible adjustment of production.

- Production time: a) reduced waiting time for order fulfillment; b) increasing the availability of machinery; c) quick start-up of machines.

As apparent from the Report of Industry 4.0 developed by PwC, the entrepreneurs who have invested in the process of digital transformation expect tangible benefits associated with the rapid transition of the fourth industrial revolution, most of all, in the form of an increase in performance, an increase in revenues and reduction of costs of the conducted activity (Raport Przemysł 4.0, 2018) - see more: Table 2.

\section{THE CONCEPT DIGITAL TRANSFORMATION IN THE ENERGY SECTOR - CASE STUDY}

An interesting example of effective implementation of changes in the business model of the organization based on the idea of Industry 4.0 is the globally operating Estonian company - Eesti Energia. It is a vertically integrated energy company. The scope of the operations of the company is production, distribution, wholesale and sales of electricity as well as mining fuels (oil shale) and production of petroleum products. The company operates mostly in Northern Europe and the Baltic countries. This 
market is characterized by high competitiveness and pressure on electricity prices. This results from its integration with the Finnish market. Since the portfolio of the generation assets of Eesti Energia is based on conventional units, the company was forced to face the falling electricity prices. The decision was made to introduce changes aimed at improving the company's performance by streamlining decisionmaking and operational processes supported by comprehensive analytical solutions based on IT.

The implementation of the program for the introduction of a new concept of the Eestii Energia operation, based on the philosophy of Industry 4.0 began in 2015 and will last until 2020. The program includes comprehensive organizational and process changes and the development of the IT area. A new business model of Eesti Energia emerged on the basis of the analysis, improvement in performance and redefinition of existing business processes. It was prepared in a manner which would improve the cooperation between individual business lines, ensure effective exchange of information and, above all, introduce the management system integrating the entire organization into one body. At the same time, the philosophy of the manner of conducting an activity was changed.

The leaders departed from the silo management concept for the benefit of the integrated value chain management. The changes in the process area triggered the reorganization of the scope of responsibility of individual business lines, organizational units and thus business objectives and performance measure systems. Process and organizational changes were, on the one hand, the reason for ordering the flow of information within the entire company, on the other, they became the source of additional information needs of the key importance for decision-making. Therefore, another step of the implementation of changes will be to provide tools essential for:

- collecting, storing and processing technological data,

- maintaining consistency, sharing and exchanging technological and business data,

- data analytics to support business processes, data visualization, etc.

IT solutions will be adjusted to such business requirements. The challenge to the organization is to order the IT solutions utilized and to introduce new systems allowing the improvement in the performance of the business process implementation. In addition, the changes will also include the integration of IT areas and production operating systems. This will allow for making business decisions quickly using analytical tools making use of the processed technological information, provided by the DCS systems. When implementing the program, Eesti Energia expects to achieve long-term effects in the form of increasing competitive advantage in the market, improving the use of the possessed resources and, most of all, more flexible decisionmaking. This will be possible through redefinition, optimization and automation of processes as well as the use of IT solutions and production operating systems (Raport Przemysł 4.0, 2018).

\section{CONCLUSION}

Industry 4.0 is characterized by the necessity to operate in a highly uncertain, turbulent environment, which is full of social, political, technological and economic changes (Geissbauer, Vedso, Schrauf, 2016). In the area of business, the 
transformation of production activities takes place, from the level of modern, independently operating enterprises to the formula of the optimally organized, fully automated networked production environments. In these networks, production, logistics and service processes of partners are strongly related through different types of sensors, machines or IT systems, thus creating the integrated Cyber-Physical Systems (CPS) communicating in real time and, on a larger scale, the so called intelligent organizations, e.g. factories, warehouses, shops. Such a system expands their value chains beyond the boundaries of individual enterprises (Kopp, Basi, 2017). Consequently, the boundaries between individual companies become blurred.

In some companies, some solutions propelling IR 4.0 already work, therefore, the question arises whether the announced transformation is actually a revolution or just a stage of the evolution of existing solutions? (Maślanek 2014; Alcácer et al. 2016). The supporters of the view that Industry 4.0 is a revolution even tend to express an opinion that such a scale is being dealt with that one may just talk about "life 4.0" since fundamental changes relate not only to industry but also the operation of public administration, health protection, labor market and thus issues such as: commuting to work, working time, organization of workstations, training, etc.

\section{REFERENCE}

Adamik A., 2018. Inteligencja organizacji $w$ erze IR 4.0, Studia i Prace Kolegium Zarządzania i Finansów, Zeszyt Naukowy No. 161.

Alcácer J., Cantwell J., Piscitello L., 2016. Internationalization in the information age: A new era for places, firms, and international business networks?, Journal of International Business Studies, No. 47.

Zakrzewska-Bielawska A., 2015. Struktury organizacyjne sprzyjające odnowie organizacyjnej przedsiębiorstw: ambidextrous approach, Management Forum, Vol. 3, No. 1.

Geissbauer R., Vedso J., Schrauf S., 2016. Industry 4.0: Building the digital enterprise: 2016 Global Industry 4.0, Survey, PwC (Pricewaterhouse Coopers).

Götz M., Gracel J., 2017. Przemysł czwartej generacji (Industry 4.0) - wyzwania dla badań w kontekście międzynarodowym, Kwartalnik Naukowy Uczelni Vistula, No. $1(51)$.

Hermann M., Pentek T., 2015. Design Principles for Industrie 4.0 Scenarios: $A$ Literature Review, Technische Universität Dortmund Fakultät Maschinenbau, Working Paper, No. 01.

Hewitt P.S., 2002. Depopulation and ageing in Europe and Japan the hazardous transition to a labor shortage economy, Internationale Politik und Gesellschaft.

Kagermann, H., Helbig, J., Hellinger, A., Wahlster, W., 2013. Recommendations for implementing the strategic initiative industrie 4.0: Securing the future of German manufacturing industry, Final report of the industrie 4.0 working group.

Kiraga K., 2016. Przemysł 4.0: 4. Rewolucja przemysłowa według Festo, Autobusy, No. 12.

Kopp J., Basi J., 2017. Study of Readiness of Czech Companies to the Industry 4.0, Journal of System Integration, No. 3.

Kościelniak H., Puto A., 2015. BIG DATA in Decision Making Processes of Enterprises, Procedia Computer Science, vol. 65.

Lee J., 2013). Industry 4.0 in Big Data Environment, German Harting Magazine. 
Maślanek J., 2014). Przemysł 4.0 - rewolucja czy ewolucja?, http://www.wnp.pl/artykuly/ [accessed on: 15.12.2018].

przemysl-4-0-rewolucja-czy-ewolucja,236764.html [accessed on: 15.12.2018].

Neeley T., 2015. Global Teams that Work, Harvard Business Review, No. 10.

Olszewski M., 2016. Mechatronizacja produktu i produkcji-przemyst 4.0., Pomiary Automatyka Robotyka 20, No. 3.

Przemysł 4.0. czyli wyzwania współczesnej produkcji, PWC, https://www.pwc.pl/przemysl4.0. [accessed on 24.02.2019]

Zagajewski A., Saniuk S., 2018. E-commerce $w$ dobie rozwoju koncepcji przemysłu 4.0, Systemy wspomagania w inżynierii produkcji, vol. 7, Issue 2.

Qin J., Liu Y., Grosvenor R., 2016. A Categorical Framework of Manufacturing for Industry 4.0 and Beyond, Procedia CIRP, vol. 52.

https://ec.europa.eu/digital-single-market/en/scoreboard/poland [accessed on 23.02.2019] 